\title{
Interview with Kevin Brownlow on the Making of Winstanley
}

\author{
By Tony Tracy
}

Fall 2010 Issue of KINEMA

KEVIN BROWNLOW is best known, and perhaps most celebrated for, his pioneering contribution as historian and champion of silent cinema. His expansive books on the period - The Parade's Gone By (1968) and the later Behind the Mask of Innocence (1990) offered unprecedented overviews of key figures and themes from an era that was all but forgotten at their time of publication, and established a field of academic enquiry that has blossomed in film studies' 'historical turn' of recent years. He is also known as the most passionate and thorough documentary chronicler of the silent era and its personalities in the many films he made over the course of thirty years and particularly in two landmark, and sadly unavailable, TV series: Hollywood - a thirteen part history produced in 1979 and Cinema Europe: the Other Hollywood (1995). Given his passion for cinema from an early age it was perhaps inevitable that Brownlow would wish to not only celebrate but emulate the silent masters and make fiction films himself; a feat he only managed to achieve twice: It Happened Here (controversial for its use of real British fascists only twenty years after the end of WWII) and Winstanley (1975). Both were low budget, odd in their subject matter, stood defiantly outside the mainstream and were, unsurprisingly, characterised by a strong visual sensibility that bore traces of influence from the silent era. The first was a re-imagining of British history where the Nazis have won the war while the second, also concerned with British history, sought to tell the story of a small seventeenth century commune and their idealistic leader Gerrard Winstanley who - some three hundred years before Russian collectivism - struggle to redefine the relations between land and those who farm it.

The British Film Institute recently completed a restoration of the original print of Winstanley in preparation for its re-release on DVD [and Blu-ray - editor's note]. Brownlow explained that the restoration project had been delayed because 'Humphries Laboratories went bankrupt and threw about 85\% of the print in a skip sometime in the early 90s'. The restoration was made possible from the remainder and existing prints.

Tony Tracy: Winstanley tells the story of its eponymous protagonist Gerrard Winstanley, a kind of Christian Communist. How did the film come about?

Kevin Brownlow: It's already thirty-five years but it seems about a fortnight ago! Andrew Mollo and I made a film when we were very young called It Happened Here (1964) about what might have happened if England had lost WWII. It took a mere eight years to make it and we were greeted by total silence from the film industry; they just didn't want to know about it. My great ambition was to become a second Orson Welles but the only job we were ever offered was second unit on [Hammer Horror] The Viking Queen and we never became professional directors in the film industry. I became an editor and Andrew became a technical advisor. We tried again and again to make another film - one of which was set in Northern Ireland in the Troubles - and eventually this story came along. Miles Halliwell [who plays Winstanley, and was a childhood friend of Mollo] found David Caute's 1961 novel Comrade Jacob set some four hundred years earlier. It seemed to be possible to do again what we did before. But although had decided to make the picture we hadn't actually managed to get the rights to the book . . . and the novelist didn't want us to make the film. He wanted Jack Gold to direct and John McGrath to write it and they couldn't get it set up either. (1) We took it around before the BFI, we took it around before the Americans and I remember one wonderful producer; he said "I read your script, it's a very wonderful script, but I don't like Winstanley! I agree you don't have to like the lead character. In Henry Levin's picture you don't like Genghis Khan, but he has a fine relationship with a girl," so at that point we gave up. To my amazement the BFI finally financed it along with some private money; the first film was made for $£ 7,000$ and nobody got paid - this one was made for $£ 24,000$ and nobody got paid either. It might have had something to do with the fact that it's not what you know in this business it's who you know. Mamoun Hassan who took over as head of the BFI Production Board was my former assistant, so it helped. He was a wonderful producer; he put aside a bit more money than he told us we had in case we ran over budget and never interfered unless we really needed something.

What elements of the story made you feel it would make an interesting subject for film? 
KB: It was incredibly English, it was full of atmosphere, and Andrew and I were fascinated by the military background. As a pacifist, I'm fascinated by war, and it had everything we needed. We were very lucky with some many things; when we came to make it, Andrew's father bought a house in Surrey which happened to have a wood in it where we could put the huts and leave them there. And five minutes up the road was that amazing hill [St George's Hill] and we could grow our own crops. Also, thirty miles outside London, you could climb on top of that hill and see that long shot. If you had gone there in 1649, it would have looked exactly the same.

Another extraordinary thing happened when we were about to do that scene on the cruciform paths. One of our favourite silent films was a German film called The Chronicles of the Gray House (Arthur von Gerlach, 1923) which was shot on the Lüneburger heath in a gale, and we screened it the night before shooting and I thought, wouldn't it be fantastic if we got the same weather conditions and we did! We got exactly the same gale.

\section{What about the story's political elements?}

KB: Well, having made a film about fascism, we were now going to make a film about socialism, and we had an historical novel, which had taken all the politics out. Winstanley was a prodigious pamphleteer so we went to the British Library and requested the original pamphlets. Then we started reading them and they were terrific - every word you hear on the soundtrack of Winstanley is unaltered from his pamphlets. He was a great writer; he was a great political thinker. He had The Communist Manifesto all laid out long before Karl Marx, only it was humanitarian and pacifist and of course Christian, because religion was so important in those days. I think David Caute, the author of the novel, felt that Winstanley was mad, and we thought he was extremely sane. I remember my wife saying 'You've got to use these' [the pamphlets] and so we jettisoned his script and most of his novel. In reality, Winstanley told us what happened - he told us the dialogue and the events and we just did it as it happened as far as we could. The only thing is, having produced what is undeniably an historically authentic film, you discover that the audiences don't give a damn.

\section{How was the political element received at the time? Did people find it a great source of discussion?}

KB: Yes, people do point out the issues. Of course in the 1970s communes like the Diggers had in fact been revived in San Francisco. The reaction was, as they say politely, 'mixed'. I must say, when you show films to people and they are present, they always tell you how wonderful it is. Josef von Sternberg says "you can rape a man's wife, you can attack his daughter, you can wipe your hands on his canary bird but you cannot say anything but 'it's a great picture." 'So I was really taken aback by some of the reviews which said it was long and boring etc, because I didn't think it was at the time. It takes a lot of concentration as it was heavily influenced by silent film and an awful lot of the information is in the visuals. I have to say the English are not a very visual people which is why we got a fantastic reaction in France. It ran for fifteen months at two theatres in Paris, I got the sort of notice you could only dream of, it was amazing. We got a few good notices in England but on the whole it was 'mixed'.

\section{What were your primary influences?}

KB: The greatest influence is Dreyer, the look of it, and particularly The Parsons Widow (Prästänkan, 1920) a wonderful film set in the $17^{\text {th }}$ century which is shot in an open museum so all the buildings are original. It's about a young man who wants to become a parson, but the parson's widow is still alive and she's 85 and he tries everything he can think of to give her a heart attack including dressing up as a dead demon, and she just roars with laughter. It's a brilliant and very touching film. But the battle scenes are stolen from Orson Welles. If you look at Chimes of Midnight, he has the most amazing battle, it's cavalry against cavalry and it happens in smoke. It looks like he's got an awful lot of troops but he hasn't. So I realised that if you established a lot of men you can then forget about it and have six men in a field. Our battle scene is six men in a field, shot in very close-up and rapidly edited, just like Orson's.

\section{How did you choose a cinematographer?}

KB: The test footage was shot by Chris Menges, who'd shot a documentary for me and we were always going to have Chris, Ernie Vinze - the eventual cinematographer - was one of his assistants. But because of budget, Ernie said that he'd do the film for nothing, but he'd have to work for a living as well. But it 
was terribly difficult, he'd come back from working on a film in Europe and then get stuck on a strike in Paris and get delayed 16 hours or whatever and we were going mad. When we started the film we did the battle scene on $16 \mathrm{~mm}$, then there was a long pause when he went off to work on something else and when he came back he seemed to have forgotten the style we had agreed upon. He shot the opening sequence, the burning of the hill, which we thought looked like television, so I was going to fire him. Then we had a crisis meeting and really started all over again. And from then on he was brilliant. Every time we saw the rushes we were thrilled. The only problem was that the lab we used destroyed a lot of the rushes and which made it difficult to maintain pictorial quality. In the end the lab went out of business and we had to go to another one. Again they didn't know how to process it and it came out looking grey and dull and boring. Then I heard that Stanley Kubrick was printing Paths of Glory there and I knew that whatever Kubrick wanted would look right, so I said do it exactly like he orders you to and ours came out looking perfect.

Was it just that they weren't pushing the stock far enough?

KB: That's right, it held them up too much, they had to alter everything too much for our little film and that annoyed them.

How long did the shoot go on for?

KB: It was only seven weeks, but it was spread over a year - shooting on weekends - because we had to have the seasons. Andrew said there's no point doing this unless we do it over the seasons, and how right he was. He also said we should shoot this in extreme long shot and then close-up and that appealed to me tremendously. The idea came from Giant, which I have never seen, which goes from an extreme long-shot to the close-up of a spur on a horse. It has always attracted me as a very dynamic way of making pictures.

Did you do a lot of storyboarding?

KB: Yes, Andrew was very contemptuous of this as he was very off-the-cuff. But it's terribly difficult to know what props to bring if you start working in that way. People wonder how on earth you can have two directors; well it's very difficult but the creative tension that is aroused between two people who think differently about how things should be done is quite exciting.

What were you trying to do? What did that tension arise from?

KB: I was politically much closer to it than Andrew was. I wanted it to be close to John Ford and The Grapes of Wrath which I think is the greatest political film. Ford was a genius, and he wasn't socialist, yet he made a purely socialist film.

Were you responsible for most of the script or was that mostly cooperative?

KB: I was walking along by the BFI at the time, I was carrying a bag and I suddenly collapsed, I had never had such pain and it couldn't have been the bag because there was nothing in it, but I realised later on that it was psychosomatic because I wasn't writing the script. We had left it to David Caute to write, and when we read it, it was not what we wanted. We didn't know how to get him to do what we wanted, so I realised I had to write the script in collaboration with Andrew. I hadn't done it, I kept putting it off, and when someone from the BFI poured me into a taxi and took me home I was put on the sofa and given a typewriter and I wrote the first draft of the script and my 'symptoms' completely disappeared. So that's filmmaking when you are completely into it, it gets you in the most extraordinary ways! Then we had somebody get in touch with us who said 'you're going to need me because you're going to need someone who understands the $17^{\text {th }}$ century and the dialogue and the language'. Since then she has become a best-selling novelist, Marina Lewycka who wrote A Short History of Tractors in Ukrainian. She helped us, in that when the characters spoke, she made sure that they spoke in the style of the $17^{\text {th }}$ century. Her boyfriend was the architectural advisor. 'You can't use that house because it was built fifty years too late and it's got flint and it should have ...!" They had read in The Times that the film was going to be made and they got in touch. It was miraculous. That's when I said there is a God and he loves filmmakers.

How did you go about constructing the sets, the huts for instance?

KB: Andrew is superb at that sort of thing. In those days wattle and daub was woven wood and cow dung, so we had something very similar, and it was wonderful to be outside, working on a film without actually working on a film. You could see when the battering ram was bashing against the sides, it didn't make much inroads - they did a very good job on it. But I'm totally impractical and so Andrew did most of that. 


\section{How big was your crew?}

KB: Oh, only about four or five people.

\section{And how did you cast the film?}

KB: Casting was the most interesting part because we couldn't afford any actor except Jerome Willis (General Fairfax) who had played Captain Gladman in the original TV adaptation of Comrade Jacob. Willis told us about Chastleton, this amazing Jacobean house from 1612 which had all the interiors we needed as well as all the original furniture. But in casting the rest Andrew felt his friend Miles Halliwell should play Winstanley. I have to admit I was not convinced. Miles was not an actor, he was a schoolteacher but then we did a test and we saw what he looked like on film and he was just transformed by the camera. To get the rest of the people and we cast on underground trains, standing outside cinemas, because the faces had to be of the $17^{\text {th }}$ century. The leading character from It Happened Here was very upset we didn't cast her, but she had a 1940s face and there's nothing we could do about it. On one occasion we saw a perfect man to play Parson Platt on the Tube, so I jumped off the train, chased him down a tunnel, explained what it was and he said 'My dear chap I'd love to do it, but you see I'm Chaplain General to the Queen'. Which was unfortunate but confirmed that I had a good eye for casting!

This interview took place at the Irish Film Institute, Dublin, where Brownlow viewed the new print of the film.

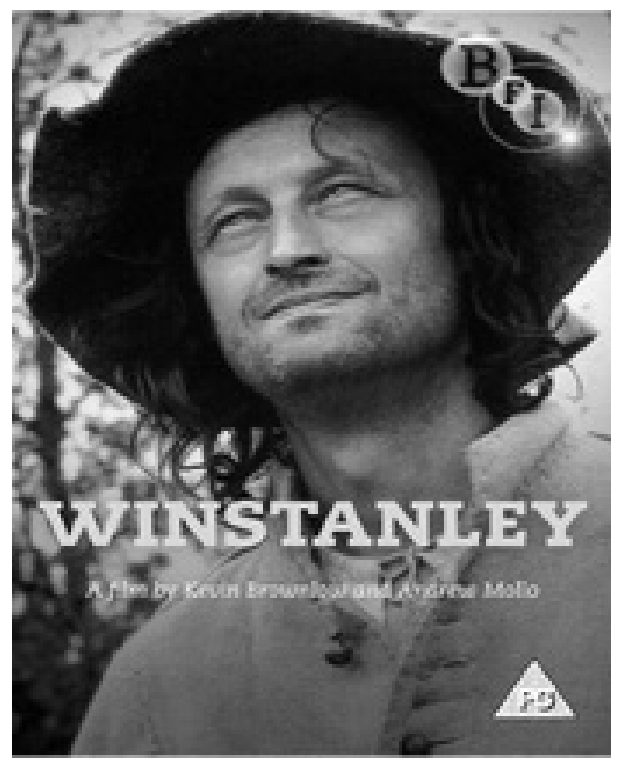

Figure 1:

\section{Notes}

1. Caute recalls that the novel attracted immediate attention from TV, drama and film producers. It was first adapted for TV (Studio 4: Comrade Jacob, September 17, 1962) and John McGrath 'adapted the novel for the stage, as the opening production of the Gardner Arts Centre at the University of Sussex.' He says that he ceded the rights to Brownlow and Mollo on condition that he would be the screenwriter but withdrew his credit when he saw the final film which he felt excluded central elements of his book: 'Wonderfully done, but now, as 30 years ago, my admiration remains somewhat rusted by regret.'

David Caute, 'Looking back in regret at Winstanley', The Guardian, 17 October 2008. http://www.guardian.co.uk/film/2008/ caute-winstanley-comrade-jacob 


\section{Author Information}

Tony TRACY is Associate Director of Huston School of Film \& Digital Media, National University of Ireland, Galway. His publications include The Films of Edgar Ulmer, McFarland; "Caught Between a Rock (Hudson) and a Raparee: Captain Lightfoot's textual heritage," in Ruth Barton (ed.), Screening Irish America: Representing Irish America in Film and Television, Irish Academic Press (2009); "This Tempting Indulgence: William McGivern's Rogue Cops," in Matthew O'Brien and James Rodgers (Eds.), After the Flood, Irish America 1945-1960. Irish Academic Press (2009). 